Котельникова, являются элементами конечномерного линейного, метрического Гильбертового пространства £ с евклидовой нормой; спектры интегральных операторов интегралов свертки задаются проекциями их ядер на ортонормированный базис тригонометрических функций. В пространстве, сопряженном с £ дискретным преобразованием Фурье определяется градиентная операция с варьируемым нецелым порядком. Итеративный оператор деконволюции изображений со всеми видами согласования его спектра с выдвигаемыми требованиями построен на преобразовании модифицированного фильтра Винера-Тихонова в геометрическую прогрессию на основании леммы Меррея об ограниченности нормы полинома, построенного на ограниченных по норме линейных операторах в Гильбертовом пространстве.

Исследование выполнено при финансовой поддержке РФФИ в рамках научных проектов №18-07-00201 «Разработка фундаментальных основ мягкого системного анализа и моделирования систем формирования и верификации космических изображений высокого и сверхвысокого разрешения по данным с группировок орбитальных аппаратов в неопределенных и предельно допустимых условиях орбитальных съемок» и №19-0700697 «Разработка основ системного анализа и моделирования коррекции резкости космических изображений сверхвысокого разрешения на базе модернизации теоретикотиповых математических и семантических подходов для прогноза и реализации максимально возможных характеристик по пространственному разрешению».

1. Винтаев, В.Н. Нетривиальная коррекция космических изображений высокого разрешения/В.Н. Винтаев, Н.Н. Ушакова//Саарбрюккен, Германия: Lambert Academic Publishing, 2018. - 208 с.

2. Макриденко, Л. А. Основные источники снижения качества изображений земли, получаемых при орбитальной оптической съёмке с борта МКА// Л.А. Макриденко, С.Н. Волков, В.Я. Геча, М.Ю. Жиленёв, С.Г. Казанцев//Вопросы электромеханики. Труды ВНИИЭМ. - 2017. - Т. 160. - С.3-19.

3. Маламед, Е.Р. Конструирование оптических приборов космического базирования /Е.Р. Маламед//С.Пб.: СПб ГИТМО(ТУ). - 2002. - 368 с.

4. Ушакова, Н.Н. Математическая модель процесса формирования космического изображения высокого и сверхвысокого разрешения в группировке космических аппаратов/Н.Н. Ушакова//Научные ведомости Белгородского государственного университета. -2016. - № 20 (44). C.155-167.

5. Финк, Л.М. Сигналы помехи ошибки/ Л.М. Финк; 2-е изд., перераб. и доп. -М.:Радио и связь, 1984.$256 \mathrm{c}$.

6. Park, S. C. Super-resolution image reconstruction: A technical overview/ S. C. Park, M. K. Park, M. G. Kang// IEEE Signal Processing Magazine. - 2003. - Vol. 20. - № 3. - P.21-36.

\title{
Корнейчук Г.К.
}

\section{Использование синергетического эффекта для создания универсального нанополимербитумного вяжущего для дорожных асфальтобетонов}

Инженерная школа Дальневосточного федерального университета

(Россия, Владивосток)

doi: 10.18411/scienceconf-05-2019-06

idsp: scienceconf-05-2019-06

\section{Аннотация}

Исследования относятся к решению двух проблем - нахождения крупнотоннажного использования шинных отходов и созданию высококачественных дорожных асфальтобетонов.

Возникающий синергетический эффект при термическом и ультразвуковом воздействии на резинобитумную смесь привел к эффективной деструкции, девулканизации резиновой крошки шинных отходов и диспергированию образовавшихся частиц до наноразмеров. В результате этих процессов получены нанополимербитумные композиции с высокими физико-механическими характеристиками, которые позволяют их использовать в качестве высокоэффективных вяжущих для получения дорожных асфальтобетонов. 
Ключевые слова: резина шинных отходов, синергетический эффект, ультразвуковая кавитация, деструкция, девулканизация, каучук, битум, полимернобитумная композиция, физико-механические характеристики вяжущего асфальтобетонов

Одними из серьезных мировых проблем являются нахождение крупнотоннажного использования шинных отходов и создание высококачественных асфальтобетонов, имеющих высокую стойкость в различных климатических условиях и при больших механических нагрузках. Особенно это важно для регионов с агрессивным климатом, характеризуемым положительными летними температурами выше $30{ }^{0} \mathrm{C}$ и отрицательными зимними ниже $-30{ }^{0} \mathrm{C}$. Актуальность такой задачи определяется тем, что в таких регионах чрезвычайно быстро разрушается асфальтовое покрытие дорог. А таких регионов много и в России и в мире.

Эти две проблемы пытались решить просто использованием резиновой крошки шинных отходов в качестве наполнителя асфальтобетонной смеси, добавляя ее в минеральную часть асфальтобетонов, вяжущим в котором являлся битум. Но в этом случае свойства асфальтобетона не улучшались, так как они определяются, в основном, физико-механическими характеристиками вяжущего. А нефтяные дорожные битумы, как известно, не обладают одновременно высокими температурами размягчения и хрупкости. Например, один из лучших битумов, выпускаемых в России, марки БНД 90/130 [1] на практике имеет лучшие температуру размягчения не более $48{ }^{0} \mathrm{C}$ и температуру хрупкости не менее $-18{ }^{0} \mathrm{C}$. При этом необходимо учесть, что температура размягчения вяжущего должна быть на $25{ }^{0} \mathrm{C}$ больше наибольшей положительной температуры в году для данного региона. Следовательно, битум марки БНД 90/130 пригоден для использования в регионах с самой высокой положительной температурой не более ... и самой низкой отрицательной температурой не менее $-22{ }^{0} \mathrm{C}$. Кроме того, они характеризуются очень низкой эластичностью (до 4 \%) и слабой адгезионной способностью к минеральным веществам (наполнителям асфальтобетонной смеси) кислой природы. Интенсивность движения и грузоподъемность автомобильного транспорта непрерывно растут и поэтому не удивительно, что в почти всех регионах России наблюдается быстрое разрушение дорожного полотна из асфальтобетона на чистом битуме. Поэтому разрабатываются способы модификации битумов для повышения их физико-механических характеристик. В настоящее время установлено, что лучшие вяжущие получаются при модификации битумов специальными каучуками - термоэластопластами. В России физикомеханические характеристики получаемых таким образом полимербитумных вяжущих (ПБВ) регламентируются ГОСТ [2]. Из него видно, например, что для у ПБВ-60 температура размягчения равна $54-56{ }^{0} \mathrm{C}$ при температуре хрупкости $-20{ }^{\circ} \mathrm{C}$. Для ПБВ-90 аналогично 51-54 и - 25. Для ПБВ-130 аналогично 49-51 и - $30{ }^{0} \mathrm{C}$. Из этих примеров видно, что если растет температура размягчения, то повышается и температура хрупкости. Поэтому невозможно получить ПБВ, удовлетворяющие регионам с одновременно летними температурами больше 30 и зимними ниже $-30^{\circ} \mathrm{C}$. Следовательно, даже в настоящее время самые лучшие вяжущие - ПБВ не отвечают оптимальным требованиям климатических условий многих регионов России и мира.

Наши разработки направлены на создание такого универсального вяжущего, которое бы по своим физико-механическим характеристикам удовлетворяло бы любым климатическим условиям.

Как сказано выше, решения проблемы крупнотоннажной утилизации шинных отходов связывали с возможностью их использования для дорожных покрытий. Однако, так как простое использование резиновой крошки шинных отходов в качестве наполнителя минеральной части асфальтобетонных смесей не привело к улучшению свойств асфальтобетона, то поэтому пошли по другому пути - созданию вяжущих, используя термическую и химическую обработку смеси битума с резиновой крошкой шинных отходов. Смысл этого сводился к тому, что при такой обработке происходила 
частичная деструкция и девулканизация резины с появлением каучуковых полимеров, которые, как известно, хорошо модифицируют битум. При этом образуется резинобитумное вяжущее (РБК) с улучшенными физико-механическими характеристиками. Однако, если считать, что эти характеристики обязаны появлению каучуковых молекул, то их появлялось немного, т.е. достигалась незначительная степень деструкции и девулканизации резины.

Для значительной степени деструкции и девулканизации шинной резины необходимо было найти новый способ. В этом направлении особенно привлекало использование ультразвуковой обработки. Например, работы $[3,4]$ показали, с одной стороны, принципиальную способность ультразвука к деструкции и девулканизации резины, но, с другой стороны, значительные технические трудности в использовании этого метода. Основным механизмом, вызывающим деструкцию и девулканизацию резины, является ультразвуковая кавитация. Надо отметить, что эксперименты в этих работах проводились, используя небольшие количества жидкости. Учитывая, что для интенсивного протекания ультразвуковой кавитации необходимого количества жидкой фазы [5], считаем, что в тех работах ее было недостаточно.

Мы с 2001 года занимаемся этой проблемой и добились четкого понимания технологических условий для активного протекания деструкции и девулканизации резины в битуме. Для этого необходима достаточно высокая температура и достаточная интенсивность ультразвукового поля. Высокая температура обеспечивает интенсивную диффузию в объемной фазе, а ультразвуковое поле ускоряет диффузию углеводородов в порах резины. На значения температуры накладывается ограничение - она не должна быть выше $180{ }^{\circ} \mathrm{C}$ во избежание интенсивного испарения легких фракций битума. Все процессы, происходящие в смеси битума с резиновой крошкой под действием термической и ультразвуковой обработки, условно можно разбить на три этапа. В результате на первом этапе резина набухает, на втором этапе ультразвуковая кавитация вызывает выбивание наполнителей резины и разрыв поперечных связей в резине. А на третьем этапе под действием ультразвуковой кавитации происходит диспергирование длинных цепочек каучуковых молекул. Этот эффект был доказан еще в работе [6].

Таким образом, термическая и ультразвуковая обработки усиливают друг друга, т.е. наблюдается синергетичесий эффект.

Этот синергетический эффект позволил получать композиции со значительно повышенными физико-механическими характеристиками. При этом самым главным является то, что были одновременно повышены температурные характеристики. Появилась возможность получать композиции с одновременно большой положительной температурой размягчения и низкой температурой хрупкости. Таким образом, значительно увеличился интервал работы композиции. Косвенно это говорит о том, что в результате описанных процессов в системе появилось значительное количество полимерных молекул каучука, которые модифицировали битум. Поэтому мы вправе называть полученные композиции полимерно-битумными. Кроме того, в [7,8] при модельном исследовании показано, что при указанных процессах происходит диспергирование частиц наполнителей резины до наноразмеров, а каучуковых полимеров до микроразмеров. Поэтому полученные полимерно-битумные композиции и, соответственно, вяжущие было решено назвать нанополимербитумными (НПБВ).

Вначале НПБВ были получены на основе смесей битума с резиновой крошкой, содержащей до $30 \%$ резины (по массе) [9], а затем и до 50 \% [10]. Причем, НПБВ, полученное на основе резинобитумной композиции с содержанием резины 50 \% (по массе) может иметь одновременно температуру размягчения до $85{ }^{0} \mathrm{C}$ и температуру хрупкости до $-50{ }^{0} \mathrm{C}$ и характеризуется эластичностью порядка $70-75 \%$ и отличной адгезией к минеральным веществам - наполнителям асфальтобетона и основной и кислой природы. Такое вяжущее может удовлетворять климатическим условиям любого региона России и мира. Поэтому его вправе называть универсальным, т.е. УНПБВ. 
Для получения нового вяжущего НПБВ нами были разработаны и сконструированы пилотные герметические установки двух типов - динамического и статического со специальным выходом для выделяющихся газов (в основном, оксидов серы и углерода). Каждая имеет свои достоинства и недостатки. Технологический контроль за процессом получения НПБВ в таких установках наиболее рационально вести по данным ротаметрической вязкости композиции при высоких температурах.

На дополнительно построенной опытной установке были выпущены несколько партий НПБВ на которых на АБЗ произведены минимальные партии нового асфальтобетона. Они были сразу использованы для создания опытных участков на активно действующей автодороге в 2016 и 2018 годах. Мониторинг этих участков показал, что новый асфальтобетон имеет гораздо выше качество, чем применявшийся на традиционном битуме БНД 90/130.

1. ГОСТ 22245 - 90. Битумы нефтяные дорожные вязкие. Технические условия.

2. ГОСТ Р 52056-2003. Вяжущие полимерно-битумные на основе блок-сополимеров типа стиролбутадиен-стирол. Технические условия.

3. US Patent No. 5, 284625. Isaev A., 1994.

4. Абрамов В.О., Абрамов О.В., Дьячковский Ф.С. и др. Девулканизация резины в ультразвуковом поле // Материаловедение. 2005. № 1. С. 3-9.

5. Хмелев В.Н., Леонов Г.В., Барсуков Р.В., Цыганок С.Н., Шалунов А.В. Ультразвуковые многофункциональные и специализированные аппараты для интенсификации технологических процессов в промышленности, сельском и домашнем хозяйстве / Алтайский гос. тенх. ун-т, БТИ. Бийск: Изд-во Алт. гос. техн. ун-та, 2007. - 400 с.

6. Маргулис, М.А. Звукохимические реакции и сонолюминисценция [Текст] / М.А. Маргулис. - М.: Химия, 1986. - 300 с.

7. Корнейчук Г.К., Буценко Ю.А. Новое высококачественное вяжущее для асфальтобетонных дорожных покрытий с эффективным использованием резины шинных отходов // Вестник Инженерной школы Дальневост. федеральн. ун-та. 2015. № 4. С. 23-28.

8. Корнейчук Г.К., Никифоров П.А., Пигильцин О.С., Буценко Ю.А. Деструкция резины под действием ультразвука // Южно-сибирский научный вестник. 2015. № 3(11). С. 41-51

9. Пат. 2489464 Российская Федерация: Способ приготовления резинобитумной композиции» / Г.К. Корнейчук; заявл. 2012127266 от 29.06.2012, зарег. 10.07.2013.

10. Пат. 2550888 Российская Федерация: Способ приготовления резинобитумной композиции / Г.К. Корнейчук; заяв. 2012154148 от 13.12.2013, зарег.15.04.2015.

\section{Мукутадзе М.А., Мукутадзе А.М., Василенко В.В., Болгова Е.А. Клиновидные опоры скольжения, обусловленных расплавом}

Ростовский государственный университет путей сообщения (Россия, Ростов-на-Дону)

doi: 10.18411/scienceconf-05-2019-07

idsp: scienceconf-05-2019-07

\section{Аннотация}

В работе дается метод формирования точного автомодельного решения задачи гидродинамического расчета клиновидной опоры скольжения (ползун, направляющая), работающей на микрополярном жидком смазочном материале, обусловленной расплавом направляющей, с учетом зависимости вязкостных характеристик микропролярного смазочного материала и проницаемости пористого слоя на поверхности ползуна от давления.

Дана оценка влияния параметров, обусловленного расплавом направляющей, структурно-вязкостных параметров микрополярного жидкого смазочного материала и проницаемости пористого слоя на несущую способность и силу трения.

Ключевые слова: опора скольжения, вязкий несжимаемый жидкий микрополярный смазочный материал, расплавленная поверхность направляющей, проницаемость пористого слоя. 